\title{
Tertiary igneous activity at Giesecke Bjerge, northern East Greenland
}

\author{
NIELS HALD்
}

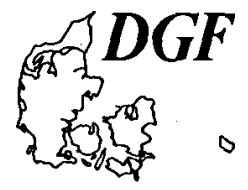

\begin{abstract}
Hald, N.: Tertiary igneous activity at Giesecke Bjerge, northern East Greenland. Bull. geol. Soc. Denmark, Vol. 27, Special Issue, pp. 109-115. Copenhagen, july 30th 1978. https://doi.org/10.37570/bgsd-1978-SI-12

The Tertiary igneous activity at Giesecke Bjerge, northern East Greenland, was initiated by the eruption of plagioclase porphyritic hyaloclastic breccias and lavas with tholeiitic affinity. These were succeeded by transitional and mildly alkaline lavas, mainly ankaramites and pyroxene-olivine porphyritic basalts. Tholeiitic sills, possibly contemporaneous with the older lavas, were intruded in the sediments beneath the volcanic sequence. Both the lavas and the sills were cut by basaltic dykes. The older lavas at Giesecke Bjerge are similar to the bulk of Tertiary lavas in East Greenland while the younger lavas show a resemblance to the Quaternary volcanic products of Jan Mayen.It is suggested that the formation and emplacement of the transitional and alkaline lavas were related to a WNW trending fracture system following Kejser Franz Josephs Fjord.
\end{abstract}

Niels Hald, Geologisk Museum, Øster Voldgade 5-7, DK-1350 Copenhagen K, Denmark. May Ist 1978.

Early Tertiary rifting prior to the opening of the Norwegian-Greenland Sea was accompanied by extrusion of flood basalts and intrusion of doleritic sills along $1000 \mathrm{~km}$ of the East Greenland coast between Kap Gustav Holm $\left(66^{\circ} 30^{\prime} \mathrm{N}\right)$ and Shannon $\left(75^{\circ} 30^{\prime} \mathrm{N}\right)$. The lavas and sills, mainly with

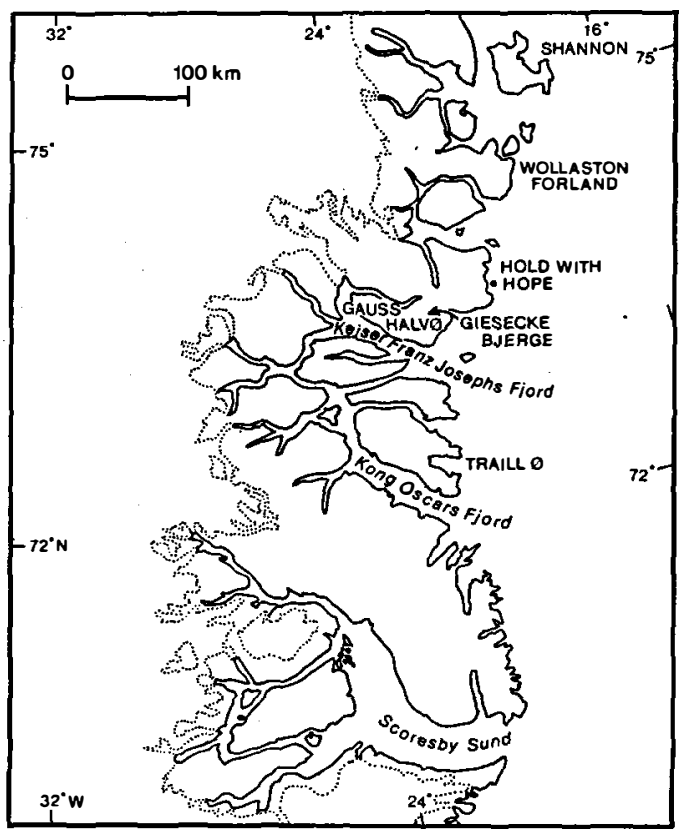

Fig. 1. The East Greenland coast between $69^{\circ} \mathrm{N}$ and $75^{\circ} \mathrm{N}$. tholeiitic affinities, were postdated by larger intrusions with a wide spectrum of tholeiitic and alkaline rock types. Recent reviews of the Tertiary igneous activity in East Greenland have been given by Brooks, Nielsen \& Petersen (1976), Deer (1976) and Noe-Nygaard (1976).

At the suggestion of Professor Noe-Nygaard detailed work has been started on the Tertiary igneous rocks at Giesecke Bjerge situated between Kejser Franz Josephs Fjord and Moskusoksefjord at $73^{\circ} \mathrm{N}$ (fig. 1). A brief note on the field work in 1977 has been given by Hald (1978); the present paper describes the results of the field work in greater detail and provides a preliminary account of the petrography of the igneous rocks.

\section{The pre-volcanic basement}

The oldest rocks at Giesecke Bjerge are Devonian, terrestrial sediments interlayered with rhyolitic lavas and tuffs, affected by 'syn-depositional' folding and faulting and intruded by granites (Graeter, 1950; Bütler, 1954). Since the Upper Paleozoic the Giesecke Bjerge area has acted as a rigid block delimited to the west by the 'post-Devonian main fault' (Vischer, 1943) and to the east by the 'Giesecke fault' (Maync, 1949). Both belong to an antithetic, coast-parallel fault system 


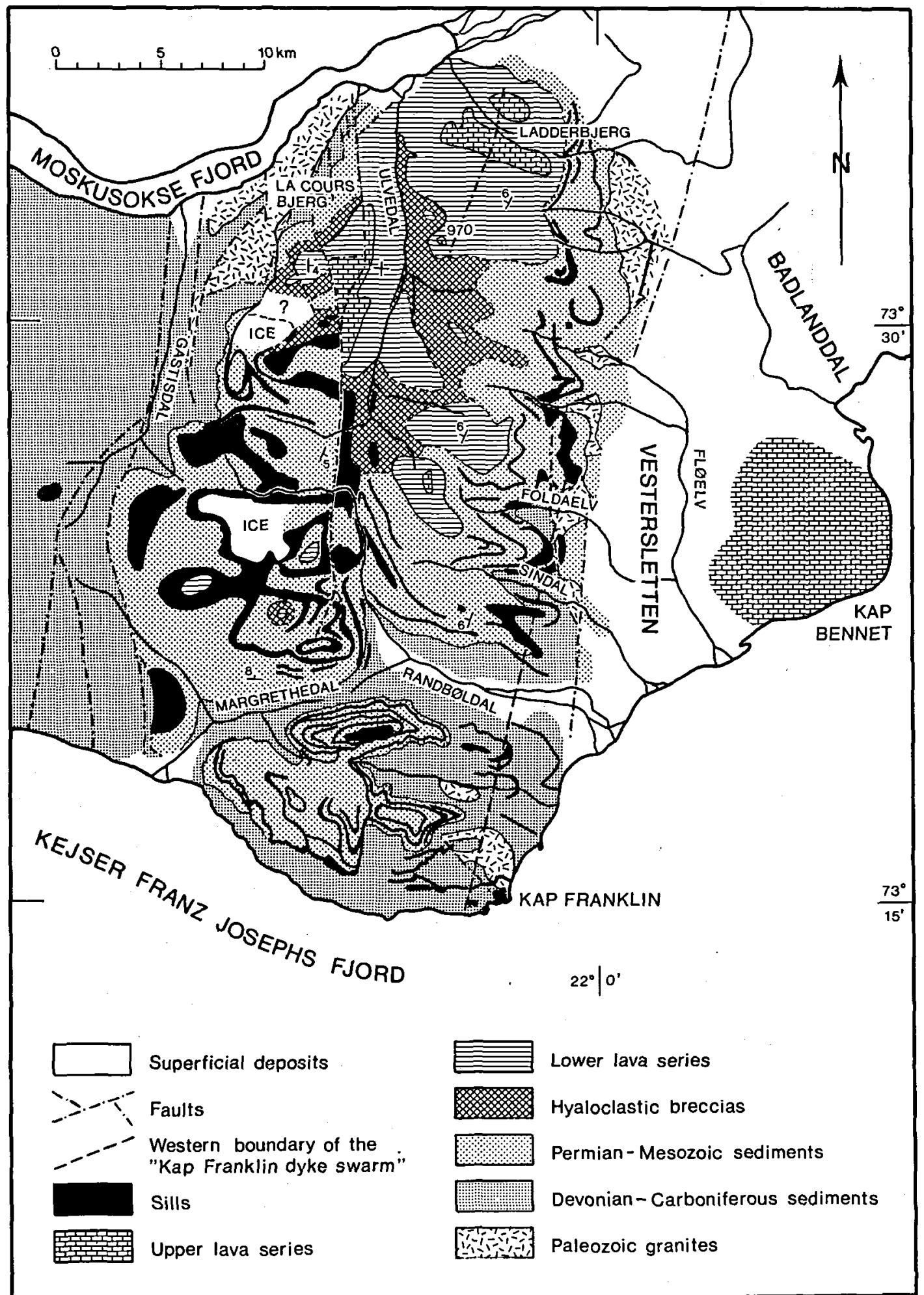

Fig. 2. Preliminary geological map of Giesecke Bjerge (Tertiary after Koch \& Haller, 1971). The signature for sills usually indisills south of Randbeldal, and pre-Tertiary geology simplified cates levels with a concentration of sills. 
established in East Greenland during the Upper Paleozoic. Continental sandstones of Carboniferous age are preserved along the east side of $\mathrm{Ga}$ stisdal. Elsewhere the Devonian rocks are covered by marine sediments: Upper Permian conglomerates, limestones and shales followed by Lower Triassic and Lower Cretaceous shales and sandstones (Maync, 1940; 1942; 1949). The youngest sediments are quartzitic conglomerates of Cretaceous or possibly Lower Tertiary age.

\section{Tertiary igneous rocks}

The Tertiary igneous rocks at Giesecke Bjerge comprise a basal hyaloclastic breccia, a sequence of lavas approximately $800 \mathrm{~m}$ thick, sills with a cumulate thickness of more than $200 \mathrm{~m}$, and dykes. Rocks of basaltic composition dominate, but rocks of trachyandesitic and basaltoandesitic composition are also found. In the areas where the breccias and lavas are still preserved, the prevolcanic relief was low. No angular unconformity has been observed between the Mesozoic sediments and the lavas.

\section{Hyaloclastic breccias}

Hyaloclastic breccias cover the Mesozoic sediments in the northern and western part of Giesecke Bjerge (fig. 2). The greatest thickness is probably attained around point 970 , where more than $300 \mathrm{~m}$ of breccias with subordinate lava flows are found (the lower boundary is not exposed). Away from point 970 the hyaloclastic breccias are covered by gradually older lavas locally with pillow breccias. Between Ulvedal and La Cours Bjerg the thickness of the hyaloclastic breccias is ca $200 \mathrm{~m}$; on the slopes facing Badlanddal and Vestersletten the breccias are absent.

The fragments in the breccias are equant, angular to subangular and typically less than $2 \mathrm{~cm}$ across. The glass, vesicular and always with microphenocrysts of plagioclase, shows various degrees of devitrification and alteration.

Larger phenocrysts of plagioclase (labradorite, bytownite), augite and pseudomorphed olivine are seen in most thin sections. The phenocryst as- semblage is similar to the assemblage found in the overlying plagioclase porphyritic lavas, and it appears that the magmas forming the breccias and the lavas were closely related.

Other rock types found as fragments in the breccias include dolerite and, rarely, sandstone.

\section{Lavas}

The lavas above the Mesozoic sediments and the hyaloclastic breccias have been grouped into a lower series of mainly plagioclase porphyritic types with a thickness of 450 m outside the breccia area, and an upper series of pyroxene-olivine porphyritic types with a maximum thickness of 350 $\mathrm{m}$ at Ladderbjerg. The boundary is well defined: plagioclase porphyritic flows have not been observed in the upper series and pyroxene-olivine porphyritic flows have not been observed in the lower series. The shift in lava composition coincides with a reversal of the magnetic field; the lavas of the lower series show reverse magnetisation while the oldest lavas of the upper series show normal magnetisation. The upper $175 \mathrm{~m}$ of lavas in the profile at Ladderbjerg were erupted during a second period of reverse polarity. Interbasaltic sediments, except for red boles and a single thin bed of arkosic sandstone, are absent.

The lavas form a soutwestward continuation of the sequence on Hold with Hope described by Upton \& Emeleus (1977). Vischer (1943) suggested that a cliff along the 'post-Devonian main fault' formed a barrier to the advance of the lavas further west. However, the scarcity of interbasaltic clastic sediments makes it unlikely that high ground was found in the immediate surroundings of Giesecke Bjerge.

The lavas of the lower series, usually of the pahoehoe type, are typically less than $10 \mathrm{~m}$ thick. Groups of thin, highly vesicular flow units are common. The phenocryst assemblage is plagioclase-olivine or plagioclase-olivine-clinopyroxene; the olivine is often replaced by sheet silicates or carbonates. The phenocrysts are typically rather small (less than $2 \mathrm{~mm}$ ), and only in a few lava flows do the phenocrysts, dominated by plagioclase, exceed 10 per cent. The groundmass has subophitic or intergranular texture with plagioclase, pyroxene, opaque minerals (titanomagnetite 

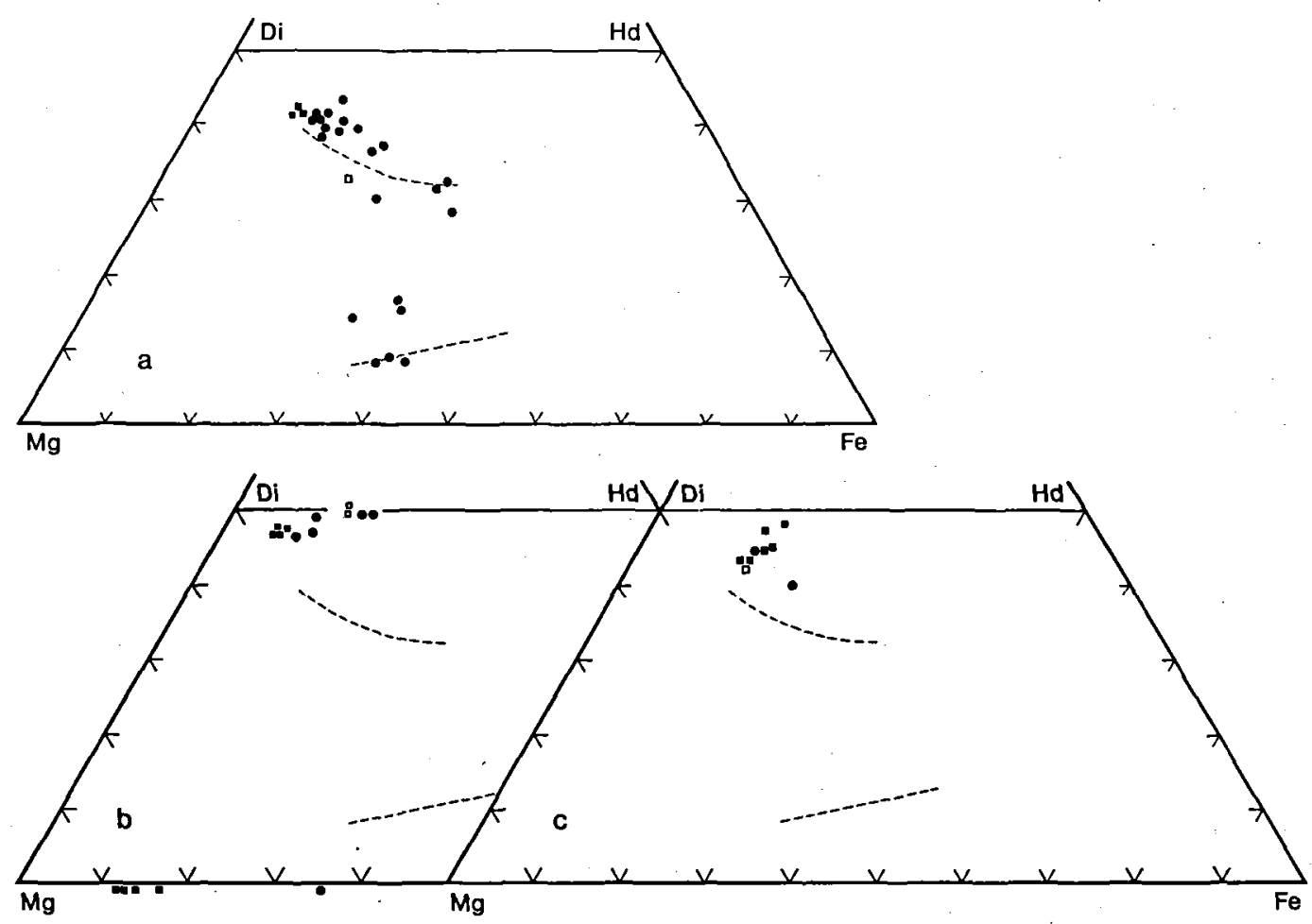

Fig. 3. Plot of olivine and pyroxene microprobe analyses. Atomic proportions. Filled squares: phenocryst cores; open squares: phenocryst rims; filled circles: grains from the groundmass. Dashed line: trend of groundmass pyroxenes from Thingmuli, Eastern Iceland (Carmichael, 1967). a. Lower series (GGU 235936 \& GGU 235946). b. Upper series (GGU 235919). c. Upper series (GGU 235924).

and ilmenite) and interstitial sheet silicates. A few lavas approximately $50 \mathrm{~m}$ below the upper boundary of the lower series differ from the main lava type by being olivine microporphyritic with a strongly poikilitic groundmass. This sequence can be followed over the greater part of northern Giesecke Bjerge. Rounded fragments of quartzitic sandstone and single rounded grains of quartz encircled by reaction rims with tiny, prismatic pyroxene crystals and brown glass occur as inclusions in a few plagioclase porphyritic lavas in the breccia complex and in the basal part of the lower lava series.

Microprobe analyses of minerals in two representative plagioclase porphyritic lavas indicate that the plagioclase phenocrysts are bytownites or calcic labradorites with rims of labradorite and andesine corresponding to the composition of the groundmass feldspar. Phenocrysts and ground- mass clinopyroxenes are augites. The latter contain $1.3 \%-3.6 \% \mathrm{Al}_{2} \mathrm{O}_{3}$ and $0.5 \%-1.7 \% \mathrm{TiO}_{2}$ (table 1, no. 3); plotted in a $\mathrm{Mg}-\mathrm{Fe}-\mathrm{Ca}$ ternary diagram (fig. 3) they follow the trend of the groundmass augites from the tholeiitic lavas of the Thingmuli volcano (Carmichael, 1967). Pigeonite is found in the groundmass of GGU 235936 (table 1, no. 2).

The chemical analyses (table 2, no. 1-2) show that the plagioclase porphyritic lavas are quartz or olivine normative tholeiites $(1.4 \%$ ol- $2.7 \% \mathrm{q})$, plotting in the tholeiitic field of the alkali-silica diagram (fig. 4), with low concentrations of $\mathrm{K}_{2} \mathrm{O}$ $(0.11 \%-0.35 \%)$ and with $\mathrm{K}_{2} \mathrm{O} / \mathrm{Na}_{2} \mathrm{O}$ ratios less than 0.15 . $\mathrm{Mg0}$ ranges between 7.5 and 5.5 and $\mathrm{Fe} 0^{t} / \mathrm{MgO}$ ratios between 1.4 and 2.7. Oxide versus $\mathrm{Fe} 0 \mathrm{t} / \mathrm{Mg0}$ trends are smooth indicating that the lavas are genetically related. The olivine microporphyritic lavas near the top of the lower series differ from the plagioclase porphyritic lavas by 
Table 1. Energy-dispersive microprobe analyses of pyroxene.

\begin{tabular}{lccccccc} 
& 1 & 2 & 3 & 4 & 5 & 6 & 7 \\
$\mathrm{SiO}_{2}$ & 52.0 & 52.4 & 50.4 & 44.5 & 48.8 & 51.3 & 44.3 \\
$\mathrm{TiO}_{2}$ & 0.45 & 0.35 & 1.1 & 3.6 & 1.6 & 1.0 & 4.1 \\
$\mathrm{Al}_{2} \mathrm{O}_{3}$ & 2.1 & 0.80 & 2.8 & 7.9 & 3.8 & 3.0 & 8.4 \\
$\mathrm{Cr}_{2} \mathrm{O}_{3}$ & 0.70 & & 0.5 & 0.15 & 0.20 & 0.60 & 0.20 \\
$\mathrm{FeO}$ & 6.7 & 23.5 & 9.2 & 9.0 & 12.0 & 4.3 & 8.8 \\
$\mathrm{MgO}$ & 16.7 & 18.9 & 14.9 & 11.9 & 13.1 & 16.2 & 11.6 \\
$\mathrm{CaO}$ & 20.1 & 3.9 & 19.7 & 21.7 & 18.8 & 22.9 & 22.3 \\
$\mathrm{Na} 2 \mathrm{O}$ & 0.20 & & 0.4 & 0.45 & 0.65 & 0.20 & 0.80 \\
\hline $\mathrm{Sum}$ & 98.95 & 99.85 & 99.0 & 99.20 & 98.95 & 99.50 & 100.50 \\
\hline $\mathrm{Mg}$ & 47.8 & 54.2 & 43.5 & 36.6 & 39.3 & 46.2 & 35.6 \\
$\mathrm{Ca}$ & 41.4 & 8.0 & 41.4 & 47.9 & 40.5 & 46.9 & 49.2 \\
$\mathrm{Fe}$ & 10.8 & 37.7 & 15.1 & 15.5 & 20.2 & 6.9 & 15.2
\end{tabular}

Anal. A. K. Pedersen, Geol. Mus. Copenhagen, using the equipment of Research School of Earth Sciences, Aust. Nat. Univ., Canberra. Method: Reed \& Ware, 1975.

1. GGU 235946. Plagioclase porph. basalt. Augite phenocryst.

2. GGU 235936. Plagioclase porph. basalt. Groundmass pigeonite.

3. GGU 235936. Plagioclase porph. basalt. Groundmass augite.

4. GGU 235924. Pyrox.-ol. porph. basalt. Salite phenocryst.

5. GGU 235924. Pyrox.-ol. porph. basalt. Groundmass augite.

6. GGU 235919. Ankaramite. Diopside phenocryst.

7. GGU 235919. Ankaramite. Groundmass salite.

lower $\mathrm{Fe} 0^{\mathrm{t}} / \mathrm{Mg} 0$ ratios (1.25) and by higher levels of $\mathrm{TiO}_{2}, \mathrm{~K}_{2} \mathrm{O}$ and $\mathrm{P}_{2} \mathrm{O}_{5}$ (table 2, no. 3).

The lavas of the upper series, characteristically with scoriaceous top layers and often covered by red boles, have an average thickness of $10 \mathrm{~m}$. The composition of the lavas grades from ankaramite to pyroxene-olivine porphyritic trachybasalt and trachyandesite.

The ankaramites often contain more than 25 per cent phenocrysts. Crystals up to $2 \mathrm{~cm}$ across of colourless to pale brown diopside (GGU 235919; table 1, no. 6 ) with rims of brownish salite dominate. Next in importance is magnesium-rich olivine $\left(\mathrm{Fo}_{85-88}\right)$. Chromite is sparse. Most ankaramites also contain a few small, lath-shaped plagioclase phenocrysts often with spotted cores. The groundmass is usually very fine grained and consists of brownish clinopyroxene, olivine, plagioclase (labradorite), alkali feldspar and opaque minerals, in some lavas with interstitial analcite. The clinopyroxenes of GGU 235919 (table 1, no. 7) are salites with $4.2 \%-8.4 \% \quad \mathrm{Al}_{2} \mathrm{O}_{3}$ and $2.1 \%-4.2 \% \quad \mathrm{TiO}_{2}$. Nodules of wehrlite, olivine-clinopyroxenite and olivine-clinopyroxene gabbro have been observed in a few flows.

In the trachybasalts and trachyandesites the phenocrysts are smaller (typically less than $1 \mathrm{~mm}$ across) and also less abundant, and some of the

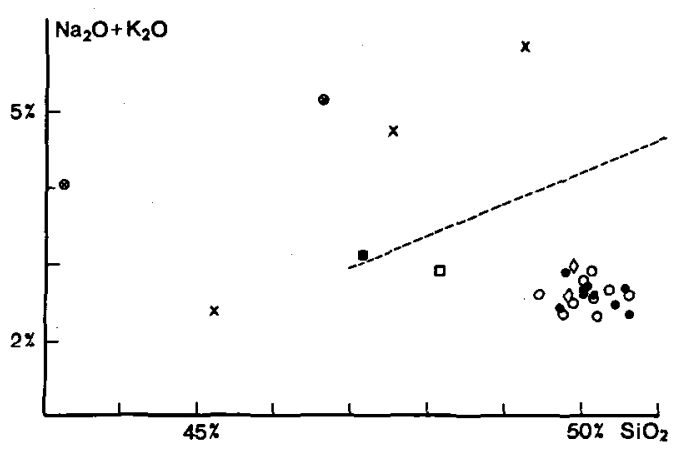

Fig. 4. Plot of total alkalies versus silica (waterfree compositions recalculated to $100 \% ; \mathrm{Fe}_{2} \mathrm{O}_{3} / \mathrm{FeO}=0.15$ ). Selected analyses. Filled circles: plagioclase porph. lavas, lower series; filled squares: olivine microporph, lavas, lower series: crosses: lavas, upper series; open circles: doleritic sills;crossed circles:pyroxeneamphibole-olivine porph. sills; open squares: WNW trending dykes; diamonds; NNE trending dykes. Also shown is the Hawaii dividing line between tholeiitic and alkaline compositions (MacDonald \& Katsura, 1964).

lavas in this group are almost aphyric. The phenocryst assemblage includes salite (GGU 235924; table 1, no. 4), pseudomorphed olivine, titanomagnetite and sparse plagioclase set in a groundmass of plagioclase, clinopyroxene (table 1 , no. 5), titanomagnetite, ilmenite, brown mica, alkali feldspar and, in some lavas, interstitial analcite. The trachyandesites characteristically show a parallel alignment of the plagioclase laths.

Compared to the plagioclase porphyritic lavas of the lower series the upper lavas are characterised by higher contents of $\mathrm{TiO}_{2}, \mathrm{~K}_{2} \mathrm{O}$, and $\mathrm{P}_{2} \mathrm{O}_{3}$ (table 2, no. 4 and 5), and they show a larger variation in chemical compositions exemplified by $\mathrm{Mg} 0$ ranging between $12.2 \%$ and $3.8 \%$ and $\mathrm{FeO} /$ $\mathrm{Mg} 0$ between 0.9 and 2.5. For the trachybasalts and trachyandesites two different 'lineages' may be distinguished, one formed by nepheline normative rocks with low $\mathrm{K}_{2} \mathrm{O} / \mathrm{Na}_{2} \mathrm{O}$ ratios $(<0.6)$, and the other formed by hypersthene normative rocks with higher $\mathrm{K}_{2} \mathrm{O} / \mathrm{Na}_{2} \mathrm{O}$ ratios $(>0.6)$.

\section{Sills}

The Mesozoic sandstones and shales, the Tertiary volcanic breccias and, less frequently, the Devonian sediments and igneous rocks are intruded by 
Table 2. Chemical composition of igneous rocks from Giesecke Bjerge, with comparisons.

\begin{tabular}{|c|c|c|c|c|c|c|c|c|c|c|c|c|c|}
\hline & 1 & 2 & 3 & 4 & 5 & 6 & 7 & 8 & 9 & 10 & 11 & 12 & 13 \\
\hline $\mathrm{SiO}_{2}$ & 49.3 & 48.9 & 45.9 & 47.7 & 43.5 & 48.8 & 49.4 & 41.6 & 46.9 & 48.5 & 48.88 & 40.00 & 46.12 \\
\hline $\mathrm{TiO}_{3}$ & 2.51 & 1.89 & 2.35 & 3.36 & 3.20 & 1.83 & 2.27 & 4.25 & 2.38 & 2.21 & 2.57 & 3.55 & 2.17 \\
\hline $\mathrm{Al}_{2} \mathrm{O}_{3}$ & 13.9 & 14.6 & 15.6 & 15.8 & 9.93 & 14.1 & 13.0 & 11.9 & 13.2 & 14.4 & 13.68 & 11.00 & 10.00 \\
\hline $\mathrm{Fe}_{2} \mathrm{O}_{3}$ & 2.66 & 3.46 & 3.09 & 4.68 & 4.43 & 2.64 & 3.37 & 4.45 & 2.95 & 4.48 & & 4.51 & 2.60 \\
\hline $\mathrm{FeO}$ & 10.74 & 7.57 & 8.41 & 6.45 & 6.59 & 9.09 & 10.02 & 7.62 & 7.80 & 6.27 & 13.43 & 7.19 & 8.76 \\
\hline MnO & 0.21 & 0.15 & 0.18 & 0.16 & 0.17 & 0.22 & 0.21 & 0.18 & 0.15 & 0.17 & 0.20 & 0.13 & 0.16 \\
\hline $\mathrm{MgO}$ & 5.78 & 7.38 & 9.58 & 4.56 & 12.2 & 7.25 & 6.64 & 9.51 & 8.16 & 7.14 & 6.57 & 7.10 & 12.30 \\
\hline $\mathrm{CaO}$ & 10.9 & 11.0 & 9.14 & 8.15 & 13.7 & 12.1 & 10.7 & 12.3 & 12.9 & 11.7 & 11.29 & 17.00 & 13.70 \\
\hline $\mathrm{Na}_{2} \mathrm{O}$ & 2.58 & 2.31 & 2.25 & 2.94 & 1.74 & 2.28 & 2.50 & 2.32 & 1.97 & 2.05 & 2.35 & 1.70 & 1.85 \\
\hline $\mathrm{K}_{\mathbf{2}} \mathrm{O}$ & 0.28 & 0.33 & 0.69 & 2.74 & 0.57 & 0.26 & 0.36 & 1.60 & 0.89 & 0.47 & 0.26 & 1.70 & 1.10 \\
\hline $\mathrm{P}_{2} \mathrm{O}_{3}$ & 0.31 & 0.18 & 0.33 & 0.62 & 0.41 & 0.16 & 0.20 & 0.83 & 0.23 & 0.22 & 0.28 & 0.86 & 0.70 \\
\hline \multirow[t]{2}{*}{$\mathrm{H}_{2} \mathrm{O}+$} & 0.96 & 1.98 & 2.47 & 2.22 & 3.06 & 1.25 & 1.72 & 3.24 & 2.27 & 2.28 & & 1.42 & 0.57 \\
\hline & 100.13 & 99.75 & 99.99 & 99.38 & 99.50 & 99.98 & 100.43 & 99.80 & 99.80 & 99.89 & 99.51 & $99.35^{*}$ & 100.03 \\
\hline
\end{tabular}

C.I.P.W. norm $\left(\mathrm{Fe}_{2} \mathrm{O}_{3} / \mathrm{FeO}=0.15\right)$

$\begin{array}{lrrrrrrrrrrrrr}\text { Q } & 0.55 & & & & & & & & & 0.16 & & \\ \text { or } & 1.65 & 1.95 & 4.08 & 16.19 & 3.37 & 1.54 & 2.13 & 9.46 & 5.26 & 2.78 & 1.54 & 10.05 & 6.50 \\ \text { ab } & 21.83 & 19.55 & 19.04 & 24.88 & 7.21 & 19.29 & 21.15 & 3.36 & 16.67 & 17.35 & 19.88 & 3.24 & 8.42 \\ \text { an } & 25.52 & 28.49 & 30.43 & 21.82 & 17.60 & 27.47 & 23.19 & 17.33 & 24.55 & 28.70 & 26.01 & 17.36 & 15.73 \\ \text { ne } & & & & & 4.07 & & & 8.82 & & & & 6.04 & 3.92 \\ \text { di } & 11.17 & 12.51 & 6.97 & 6.57 & 29.11 & 15.15 & 12.70 & 22.08 & 20.31 & 14.27 & 12.44 & 21.54 & 27.80 \\ \text { hd } & 10.86 & 7.87 & 3.40 & 5.46 & 9.18 & 10.75 & 10.94 & 8.83 & 10.57 & 8.53 & 10.86 & 12.05 & 10.65 \\ \text { en } & 9.22 & 11.45 & 6.38 & 0.21 & & 7.68 & 10.56 & & 0.68 & 11.17 & 9.92 & & \\ \text { fs } & 10.28 & 8.27 & 3.57 & 0.20 & & 6.25 & 10.44 & & 0.41 & 7.66 & 9.94 & \\ \text { fo } & & 0.79 & 9.98 & 5.67 & 11.84 & 2.35 & 0.06 & 9.43 & 7.17 & & 0.47 & 5.39 & 12.44 \\ \text { fa } & & 0.63 & 6.15 & 5.96 & 4.72 & 2.11 & 0.07 & 4.77 & 4.72 & & 0.52 & 3.81 & 6.02 \\ \text { mt } & 2.52 & 2.04 & 2.15 & 2.04 & 2.03 & 2.20 & 2.51 & 2.23 & 2.00 & 1.97 & 2.57 & 2.16 & 2.13 \\ \text { it } & 4.77 & 3.59 & 4.46 & 6.38 & 6.08 & 3.48 & 4.31 & 8.07 & 4.52 & 4.20 & 4.88 & 6.74 & 4.12 \\ \text { ap } & 0.73 & 0.43 & 0.78 & 1.47 & 0.97 & 0.38 & 0.47 & 1.97 & 0.54 & 0.52 & 0.66 & 2.04 & 1.66\end{array}$

Anal. Ib Sørensen, Geol. Surv. Greenland. $\mathrm{FeO}$ : wet chemical methods; $\mathrm{Na}_{2} \mathrm{O}$ : atomic absorption; $\mathrm{H}_{2} \mathrm{O}+:$ loss on ignition; other elements: XRF on glass discs. - * Includes $3.19 \% \mathrm{CO}_{2}$ and norm includes $7.25 \% \mathrm{cc}$.

1. GGU 235822 Plagioclase porph. basalt, lower series. Margrethedal.

2. GGU 235936 Plagioclase porph. basalt, lower series. Ladderbjerg.

3. GGU 235933 Olivine microporph. basalt, lower series. Ladderbjerg.

4. GGU 235924 Pyroxene-olivine porph. basalt, upper series. Ladderbjerg.

5. GGU 235919 Ankaramite, upper series. Ladderbjerg.

6. GGU 200267 Doleritic sill. Randbøldal.

7. GGU 235954 Doleritic sill. Ladderbjerg.
8. GGU 200162 Mafic sill with phenocrysts of clinopyroxene, olivine, amphibole, mica and opaque minerals. Ladderbjerg.

9. GGU 235939 WNW trending, basaltic dyke. Ladderbjerg.

10. GGU 200171 N-NE trending, basaltic dyke. Sindal.

11. Average Blosseville Coast lava. (Brooks, Nielsen \& Petersen, 1976).

12. HK 114. Ankaramitic sill. Theresabjerg south of Kong Oscars Fjord. (Kapp, 1960).

13. NC 27K. Trachybasalt. Jan Mayen. (Hawkins \& Roberts, 1972).

Lavas 1 to 5 in ascending order.

always present in the chill zones; they may be accompanied by microphenocrysts of pseudomorphed olivine and colourless to pale brown clinopyroxene. Layered inclusions, several metres in size, of baked slate and sandstone have been found in doleritic sills on Ladderbjerg and north of Margrethedal. Chemically the doleritic sills may be classified as olivine or quartz normative tholeiites. In major element composition the sills can hardly be distinguished from the plagioclase porphyritic lavas of the lower series (table 2, no. 6 and 7; fig. 4).

Sills of ankaramite or pyroxene-olivine porphy- 
ritic basalt have not been observed despite the common occurrence of these rock types among the lavas, but a few mafic, clinopyroxene-amphiboleolivine porphyritic sills were intruded in the granites and Mesozoic sediments on the eastern slopes of Ladderbjerg (table 2, no. 8).

The age of the sills is uncertain, but the similar major element compositions and phenocryst assemblages suggest that the dolerites are contemporaneous with the plagioclase porphyritic lavas of the lower series. In addition the bulk of doleritic sills are reversely magnetised, as are the lower lavas, and both are cut by the late dykes described below.

\section{Dykes}

Two dyke trends have been recognised. WNW trending dykes, some with normal and others with reverse magnetisation, can be found in most parts of Giesecke Bjerge, but are rare. They cut the doleritic sills and the plagioclase porphyritic lavas of the lower series while their relationship to the upper series is unknown. N-NE trending dykes, all intruded during a period of normal magnetisation, are found along the eastern slopes of Giesecke Bjerge between Kap Franklin and Fløelv, and around Kap Bennet. In the latter area they cut through lavas which are correlated with the upper series at Giesecke Bjerge (Hald, 1978). Only one intersection between the two dyke trends is known; a WNW trending dyke is cut by a member of the N-NE trending 'Kap Franklin dyke swarm'.

Dykes of both trends have basaltic compositions and the more fine grained rocks contain phenocrysts or microphenocrysts of plagioclase, olivine and sometimes clinopyroxene. Many of the dykes in the 'Kap Franklin dyke swarm' contain sulphides both as poikilitic globules up to $1 \mathrm{~cm}$ across and disseminated in the groundmass. A considerable overlap in chemical compositions of the dykes from the two trends is found. The dykes are quartz or olivine normative tholeiites (table 2, no. 9 and 10) and in this respect show resemblance to the lower lavas. However, the dykes are typically slightly enriched in $\mathrm{K}_{2} \mathrm{O}$ and $\mathrm{TiO}_{2}$. $\mathrm{MgO}$ ranges between $8.2 \%$ and $3.4 \%$ and $\mathrm{Fe} 0 \mathrm{t} / \mathrm{Mg} 0$ ratios between 1.3 and 3.8. A few ankaramitic dykes are also included in the Kap Franklin swarm.

\section{Post-volcanic tectonics}

There is no evidence of faulting or tilting of the Giesecke Bjerge area during the formation of the lava pile. At a later date the 'post-Devonian main fault' and the 'Giesecke fault' were reactivated with downthrows to the east. A major N-S trending fault, also with downthrow to the east, bisected Giesecke Bjerge. It separates WNW-dipping lavas to the east and E-dipping lavas to the west. The fault gradually dies out.southwards corresponding to a southward increase in the post-volcanic displacement along the 'Giesecke fault' (cf. Maync, 1949).

The WNW trend shown by the dykes and also found among the valleys in Giesecke Bjerge is assumed to reflect zones of weakness parallel to Kejser Franz Josephs Fjord. No faulting parallel to this direction has been noted.

\section{Discussion}

The igneous activity in Giesecke Bjerge has been divided into three stages: (1) Eruption of hyaloclastic breccias and plagioclase porphyritic tholeiitic lavas on a pre-volcanic surface partially covered by water during a period of reverse magnetisation. The bulk of the tholeitic sills was probably intruded during this stage. (2) Eruption of ankaramites and pyroxene-olivine porphyritic trachybasalts of transitional and mildly alkaline affinity during two periods of normal and reverse magnetisation respectively. (3) Resumption of plagioclase porphyritic, tholeiitic activity with intrusion or N-NE trending dykes during a period of normal magnetisation. The position of the WNW trending dykes in this scheme is uncertain. They are younger than the lower lavas, but may all predate the N-NE trending dykes.

The tholeiitic lavas and sills have close affinities to tholeiites elsewhere in the Tertiary East Greenland province: the lavas at Kap Stosch (Noe-Nygaard \& Pedersen, 1974); the lavas, sills and dykes north of $74^{\circ} \mathrm{N}$ (unpublished analyses by $A$. NoeNygaard and the author) and the lavas south of Scoresby Sund (Brooks, Nielsen \& Petersen, 1976) (table 2, no. 11). Igneous rocks similar to the lavas of the upper series with transitional and mildly alkaline affinities and with increased $\mathrm{K}_{2} \mathrm{O} / \mathrm{Na}_{2} \mathrm{O}$ ratios are less common in East Greenland. Two ex- 
amples are the sills and dykes found along Kong Oscars Fjord (Kapp, 1960) (table 2, no. 12) and the lavas and dykes from the nunatak zone at $74^{\circ} \mathrm{N}$ (Katz, 1952). However, the rocks from both areas are generally more undersaturated than the upper lavas at Giesecke Bjerge.

In addition the upper lavas resemble the Quaternary ankaramites and trachybasalts of Jan Mayen which are also characterised by high $\mathrm{K}_{2} \mathrm{O} / \mathrm{Na}_{2} \mathrm{O}$ ratios (cf. Tyrrell, 1932) (table 2, no. 13). The island is situated above the south wall of the WNW-trending Jan Mayen Fracture Zone. Sylvester (1976) supposes that the volcanic activity on Jan Mayen is related to this structure.

Faulting along Kejser Franz Josephs Fjord is assumed to have taken place during the Mesozoic (Surlyk, 1977), and the presence of WNW-trending dykes in Giesecke Bjerge shows that fracturing parallel to the fjord resumed during the Lower Tertiary. Kong Oscars Fjord was also the site of Mesozoic faulting (Birkelund \& Perch-Nielsen, 1976) and Lower Tertiary 'fjord-parallel' dykes are found on southern Traill $\emptyset$. The two fault zones are both parallel to the western Jan Mayen Fracture Zone which is probably situated on acontinuation of the older faults in Kejser Franz Josephs Fjord (Surlyk, 1978). It is suggested that the alkaline igneous activity at Giesecke Bjerge (and perhaps also along Kong Oscars Fjord) is broadly related to the WNW-trending fault zones, although it should be noted, that mapping in Giesecke Bjerge has not shown any relationship between the ankaramites and pyroxene-olivine porphyritic basalts and the WNW-trending structural elements. It has been proposed that alkaline magmas are generated at greater depths in the earth's mantle than tholeiites (Green \& Ringwood, 1967); the intersection of the 'fjord-parallel' faults and the East Greenland coast-parallel fault system may have created easy access for the alkaline magmas to ascend towards the surface.

Acknowledgements. The author wishes to thank C.K. Brooks, S.P. Jakobsson and T.F.D. Nielsen for critical comments. Thanks are also due to I. Sørensen for the rock analyses, to A. K. Pedersen for the microprobe analyses and to A. Steenfelt for permission to use 3 analyses of rocks from Giesecke Bjerge. The field work was carried out under the auspices of the Geological Survey of Greenland, and the results are published with the permission of the Director.

\section{Dansk sammendrag}

Den tertiære vulkanske aktivitet i Giesecke Bjerge, beliggende i den nordlige del af Østgrønland mellem Kejser Franz Josephs Fjord og Moskusoksefjord, indledes med dannelsen af plagioklasporfyriske, basaltiske breccier og lavaer. Disse er overlejret af basaltiske lavaer, hvor clinopyroxen er det vigtigste strokornsmineral. Mægtigheden af den bevarede del af den vulkanske lagserie er $800 \mathrm{~m}$. Doleritiske sills med en samlet mægtighed pà over $200 \mathrm{~m}$ er intruderet $\mathrm{i}$ de underliggende palæozoiske og mesozoiske sedimenter, formodentlig samtidig med, at de ældre lavaer kom til udbrud. Basaltiske dykes, parallelle med Kejser Franz Josephs Fjord (VNV), skærer de nedre lavaer og de doleritiske sills, mens relationen til de øvre lavaer er ukendt. Yngst er basaltiske dykes, der stryger N-NØ. Kemisk er de plagioklasporfyriske lavaer nært beslægtede med andre tertiære lavaer fra Østgronland, mens de pyroxenporfyriske basalter viser lighed med kvartære udbrudsprodukter fra Jan Mayen. Det foreslàs, at tilstedeværelsen af de pyroxenporfyriske basalter i Giesecke Bjerge er betinget af VNV-gående opsprækningszoner langs Kejser Franz Josephs Fjord.

\section{References}

Birkelund, T. \& Perch-Nielsen, K. 1976: Late Palaeozoic-Mesozoic evolution of central East Greenland. In: Escher, A. \& Watt, W.S. (eds.): Geology of Greenland, 304-339. Copenhagen: Geol. Surv. of Greenland.

Brooks, C.K., Nielsen, T.F.D. \& Petersen, T.S. 1976: The Blosseville Coast basalts of East Greenland: their occurrence, composition and temporal variations. Contr. Mineral. Petrol. 58, 279-292.

Bütler, H. 1954: Die stratigraphische Gliederung der Mitteldevonischen Serien im Gebiete von Kap Franklin am Kejser Franz Josephs Fjord in Zentral-Ostgrönland. Meddr Grenland $116,7,126 \mathrm{pp}$.

Carmichael, I.S.E. 1967: The mineralogy of Thingmuli, a Tertiary volcano in eastern Iceland. Am. Miner. 52, 1815-1841.

Deer, W.A. 1976: Tertiary igneous rocks between Scoresby Sund and Kap Gustav Holm, East Greenland. In: Escher, A. \& Watt, W.S. (eds): Geology of Greenland, 404-429. Copenhagen: Geol. Surv. of Greenland.

Graeter, P. 1957: Die sauren devonischen Eruptivgesteine des Kap Franklingebiets am Kejser Franz Josephs Fjord in Zentral-Ostgrönland. Meddr Grønland 155, 3, 102 pp.

Green, D.H. \& Ringwood, A.E. 1967: The genesis of basalt magmas. Contr. Mineral. Petrol. 15, 103-190.

Hald, N. 1978: Field investigations on lower Tertiary basic, igneous rocks between $72^{\circ}$ and $73^{\circ} 30^{\circ} \mathrm{N}$, northern East Green. land. Rapp. Grenlands geol. Unders. 90.

Hawkins, T.R.W. \& Roberts, B. 1972: The petrology of the volcanic and intrusive rocks of Nord-Jan, Jan Mayen. Norsk polarinst. Arbok 1970, 19-41.

Kapp, H. 1960: Zur Petrologie der Subvulkane zwischen Mesters Vig und Antaretic Havn (Ost-Grönland). Meddr Gronland 153, 2, $203 \mathrm{pp}$.

Katz, H.R. 1952: Ein Querschnitt durch die Nunatakzone Ostgrönlands. Meddr Gronland 144, 8, 65 pp.

Koch, L. \& Haller, J. 1971: Geological map of East Greenland $72^{\circ}-76^{\circ}$ N. Lat. (1:250.000). Meddr Grenland 183, $26 \mathrm{pp}$.

MacDonald, G.A. \& Katsura, T. 1964: Chemical composition of Hawaiian lavas. J. Petrol. 5, 82-133.

Maync, W. 1940: Stratigraphie des Küstengebietes von Ostgrönland zwischen $73-75^{\circ} \mathrm{N}$. Lat. (Östliche Gauss Halvg, Holdwith-Hope, östliche Clavering $\emptyset$, Wollaston Forland, Kuhn $\emptyset$, Sabine $\emptyset$ und Lille Pendulum Ø). Meddr Grønland 114, $5,34 \mathrm{pp}$. 
Maync, W. 1942: Stratigraphie und Faziesverhältnisse der oberpermischen Ablagerungen Ostgrönlands (olim "OberkarbonUnterperm") zwischen Wollaston Forland und dem Kejser Franz Josephs Fjord. Meddr Gronland 115, 2, 128 pp.

Maync, W. 1949: The Cretaceous beds between Kuhn Island and Cape Franklin (Gauss Peninsula), northern East Greenland. Meddr Gronland 133, 3, 291 pp.

Noe-Nygaard, A. 1976: Tertiary igneous rocks between Shannon and Scoresby Sund, East Greenland. In: Escher, A. \& Watt, W.S. (eds.): Geogoly of Greenland, 386-402. Copenhagen: Geol. Surv. of Greenland.

Noe-Nygaard, A. \& Pedersen, A.K. 1974: Progressive chemical variation in a tholeiitic lava sequence at Kap Stosch, northern East Greenland. Bull. geol. Soc. Denmark 23, 175-190.

Reed, S.J.B. \& Ware, N.G. 1975: Quantitative electron microprobe analyses of silicates using energy-dispersive $\mathrm{X}$-ray spectrometry. J. Petrol. 16, 499-519.

Surlyck, F. 1977: Mesozoic faulting in East Greenland. In: Frost, R.T.C. \& Dikkers, A.J. (eds.): Fault tectonics in N.W. Europe. Geol. Mijnb. 56, 311-327.

Surlyk, F. 1978: Jurassic basin evolution of East Greenland. Nature 274, 130-133.

Sylvester, A.G. 1976: History and surveillance of volcanic activity of Jan Mayen Island. Bull. Volcan. 39, 313-335.

Tyrrell, G.W. 1932: The petrography of some Kainozoic igneous rocks, and of the Cape Parry alkaline complex, East Greenland. Geol. Mag. 69, 520-527.

Upton, B.G.J. \& Emeleus, C.H. 1977: The Tertiary geology of Hold with Hope, northern East Greenland. Rapp. Gronlands geol. Unders. 85, 115-121.

Vischer, A. 1943: Die postdevonische Tektonik von Ostgrönland zwischen $74^{\circ}$ und $75^{\circ} \mathrm{N}$. Br. Kuhn $\emptyset$, Wollaston Forland, Clavering $\varnothing$ und angrenzende Gebiete. Meddr Gronland $133,1,194 \mathrm{pp}$. 